\title{
Mycorrhizal fungi associated with plantations of Pinus taeda L. from the National University of Asunción, Paraguay
}

\section{Campi MG ${ }^{1}$, Maubet $\mathrm{YE}^{1}$ and Britos $\mathrm{L}^{1}$} ${ }^{1}$ Universidad Nacional de Asunción, Av. Mcal López 3492 cl 26 de Febrero, San Lorenzo, Paraguay.
geraldine_campi@hotmail.com, ymaubet@gmail.com,lizbritos1985@gmail.com

Campi MG, Maubet YE, Britos L 2015 - Mycorrhizal fungi associated with plantations of Pinus taeda L. from the National University of Asunción, Paraguay. Mycosphere 6(4), 486-492, Doi 10.5943/mycosphere/6/4/10

\begin{abstract}
Four species of ectomycorrhizal fungi associated with Pinus taeda L. are cited. This species is estimated to have been introduced to Paraguay during the 20th century and the mycorrhizal mushrooms were inoculated in the roots of the trees, therefore they are considered non-native species. Geastrum minumun Schwein., Pisolithus arrizhus (Scop.) Rauschert, Suillus granulatus and Scleroderma bovista Fr. are cited for the first time for Paraguay. The macroscopic and microscopic characteristics are included as well as a brief description of Pinus taeda L. .
\end{abstract}

Key words - ectomycorrhizal - exotic fungi - gymnosperms

\section{Introduction}

Mycorrhizal fungi are those that form mutualistic associations with plants. The main benefit of the symbiotic association lies in the exchange of nutrients. The consequence of the ability of mycorrhizal fungi to intercede in the process of release of nitrogen $(\mathrm{N})$ and phosphorus $(\mathrm{P})$ in its ionic form can be considered not only in terms of preferential supply of nutrients to the host plant, but also on early intervention in the event of mineralization, reducing the supply of $\mathrm{P}$ and $\mathrm{N}$ in ionic form required for non-mycorrhizal competitors. Analytical studies reveal that the most abundant symbiotic relationship is with the group of Basidiomycota (Becerra \& Zak 2011, Read \& PerezMoreno 2003).

Extensive plantations of exotic pine, mainly Pinus radiata have been (and continue to be) settled in the Southern Hemisphere, from the second half of the 9 9 th century. For example, 1.5 million hectares have been introduced in Chile, more than 1 million hectares in New Zealand, more than 700,000 hectares in South Africa, and 800000 ha in Australia (Dustamet al. 1998).

In Paraguay, the first plantations, usually in small areas, were established before and during World War II by private owners and companies like Fassardi Ltd. (Plantations of eucalyptus and cedar), the "Azucarera Paraguaya SA" (400-500 ha of eucalyptus plantations, mainly E. saligna), aimed at the production of industrial wood. Between 1955 and 1966, the National Agricultural Institute (IAN), emphasized the production of exotic plants and over 100 exotic tree species were planted for research purposes. Of the 18 species of tropical and subtropical pines introduced in 1959, only three stayed as better adapted: Pinus elliottii Engelm., P. taeda L., P. caribaea var. caribaea Morelet, also emerged trials with plantations of native species "Peterevy" (Cordia trichotoma) (Vell.) Steud.) and Paraná pine (Araucaria angustifolia (Bertol.) Kuntze). By the end of 1980, the total planted area in the country was approximately 3.800 ha. Between the month of 
may and june of 1.981, the Directorate of the Department of Forest Production from the Faculty of Agricultural Engineering (FIA), installed in their fields plantation trials of $P$. elliottii y P. taeda, in strips of $230 \times 24$ meters north-south and remnants of these pine plantations of over 30 years old are left today. The seeds were obtained from the US Forest Tree Seed Center, in 1980-1981. The origin of P. taeda covers the east of Texas to Georgia and west Florida (Enciso 2002, Noguera 2003, Larrobla \& Berni 1982 López 1974).

With the introduction of these tree species, several ectomycorrhizal fungi were also introduced and established in exotic plantations (Nouhra et al. 2012).

To generate and enrich the information on the study of mycorrhizal fungi introduced to Paraguay with exotic pine species and expand the known facts of the exotic species introduced, $P$. taeda, G. minimun, P. arrizhus, S. granulatus and S. bovista are described, representing the first records for Paraguay, and the exotic species $P$. taeda is also taxonomically characterized.

\section{Materials \& Methods}

Samples collected from plantations of Pinus taeda located inside the campus of the National University of Asunción were analyzed at the Laboratory of Analysis of Plant Resources and deposited in the herbarium of the Faculty of Natural and Exact Sciences, National University of Asunción. The sample corresponding to the species P. taeda was deposited in the Herbarium of the Faculty of Chemistry (HFCQ) from the National University of Paraguay. Macroscopic data of size, color and consistency refer to fresh material. For microscopic study of structures, $\mathrm{KOH}$ preparations were analyzed at 5\%. Samples were observed through an optical microscope with 40X and 100X objectives with immersion oil. Vegetative structures (capillitium hyphae) were stained with Congo red and Phloxine. The materials are preserved in the herbarium of the Faculty of Natural and Exact Sciences (FACEN) of the National University of Asunción, except for samples belonging to the Scleroderma bovista species, which were deposited in the herbarium of the University of Alcalá de Henares.

\section{Results}

\section{Pinus taeda L., Species Plantarum 2: 1000. 1753.}

Known distribution $-P$. taeda is native to the southeastern United States, crossing the Mississippi River and spanning across the states of Arkansas and Texas. It grows mostly on brittle land. In the north it develops especially over dry and sandy soils; further south, preferably in low and wet land, it is found in areas of low to medium altitude and temperate climate - warm and rainy summer (Figueroa 2007). In Paraguay it is common in the Departments of Cordillera, Central, Alto Paraná and Itapúa (Larrobla \& Berni 1982, Morales et al. 2002, Noguera 2003).

Material examined - Paraguay, Central Department, City of San Lorenzo, University Campus, Nov 2014, L. Britos 35 (HFCQ).

Geastrum minimum Schwein., Schrften Naturf.Ges. Leizig 1: 58 (1822)

Figs. 7, 8, 9-11

Mature basidiomata expanded, epigeous, small, star-shaped, $3.5 \mathrm{~cm}$ diam. Exoperidium sacshaped, whitish gray, opening from the apex in 5-10 rays. The rays are triangular and medium-sized at maturity, $1 \mathrm{~cm}$ length and different diameters, whitish to gray; non-hygroscopic, papyraceous when dry, beige. Mycelial layer with abundant detritus and incrustations strongly adhered to the outer layer by a whitish mycelium, mixed with organic matter and sand, this makes the mycelial layer inappreciable; hyphae from the mycelial layer 1-2 $\mu \mathrm{m}$ diam., hyaline, thin-walled, narrow lumen, with septa and clamps. Fibrous layer beige to yellowish white, hyphae 4-6 $\mu \mathrm{m}$ diam., parallel, smooth, hyaline, narrow lumen, strongly intertwined. Pseudoparenchymatous layer whitish to gray when fresh, beige and slightly brittle when dry, hyphae of different shapes and sizes: angular, rounded or isodiametric 30-50 $\times 20-30 \mu \mathrm{m}$, hyaline with thin walls. Endoperidium globose to sac-shaped, 1-1.5 high $\times 0.5-1 \mathrm{~cm}$ diam., gray, in mature samples gray to brownish gray. In the apex it presents a peristome delimited by a white ring of $4 \mathrm{~mm}$ diam., not very evident, of a clearer tone than the rest of the endoperidial surface, crowned by a fibrillose ostiole, $0.5-1 \mathrm{~mm}$ 

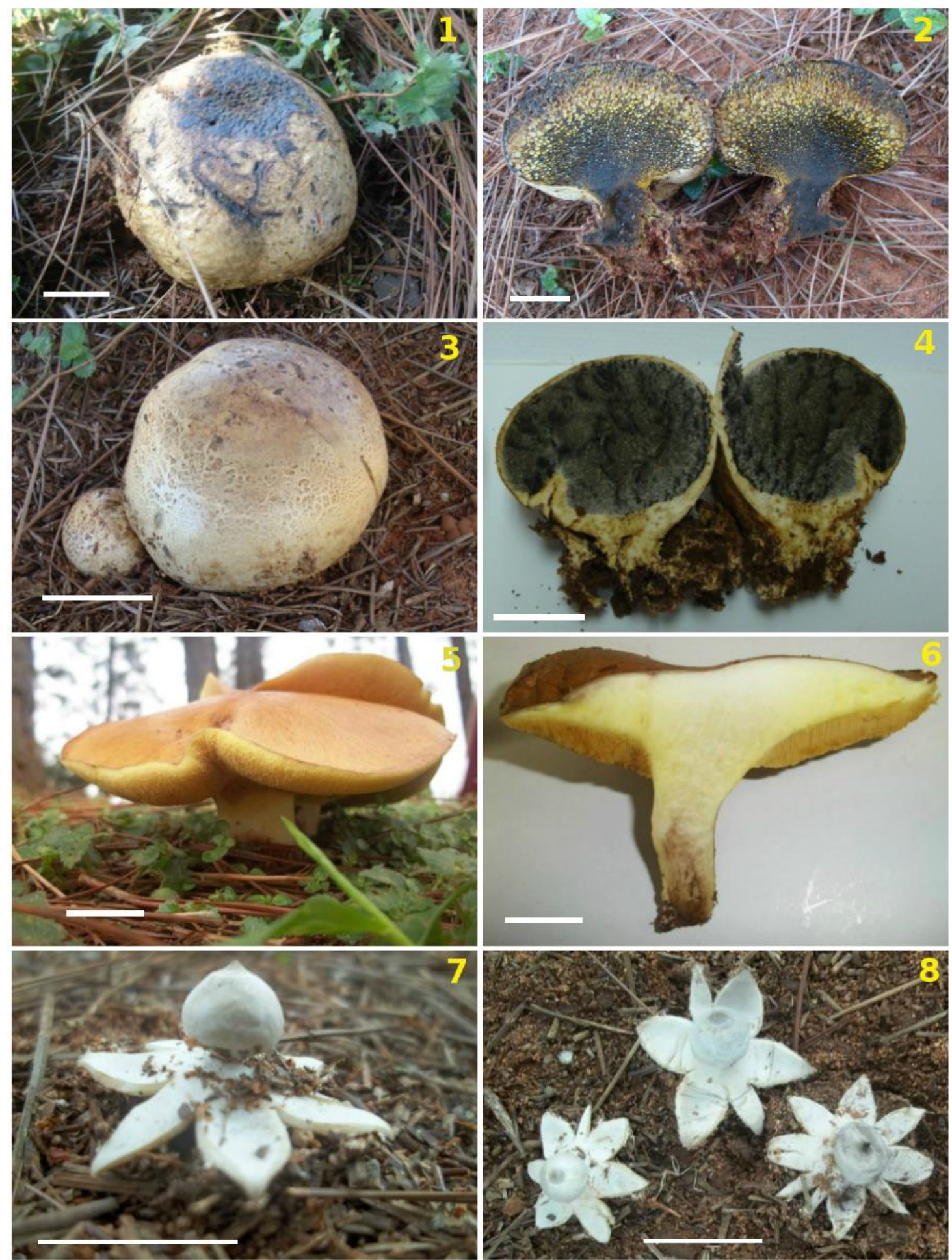

Figs 1-6 - Basidiomata of fungi associated to Pinus taeda plantations 1 Pisolithus arhizus 2 P. arhizus in transversal section 3 Scleroderma bovista 4 S. bovista in transversal section 5 Suillus granulatus $6 S$. granulatus in transversal section 7 Geastrum minimun 8 G. minimun in colonies

diam.; on very mature samples the peristome does not seem delimited since it takes the same color as the endoperidium and the ostiole presents a darker brown colour. Endoperidium hyphae 3.5-5 $\mu \mathrm{m}$, thin-walled, smooth, narrow lumen. Capillicium hyphae 3-8 $\mu \mathrm{m}$ diam., yellowish to brown on $\mathrm{KOH}$, some with thin walls, others with thick walls up to $3 \mu \mathrm{m}$ diam. Mature basidiospores $3-5 \mu \mathrm{m}$ diam., globose, warty, brown to golden brown and a short pedicel in the apex. Immature spores hyaline, at first subovoid, then globose. 
Habitat - Gregarious or solitary, growing on soil.

Known distribution - In Costa Rica cited for the first time by Calonge et al.(2005); in Brazil, for the States of Rio Grande do Norte (Fazolino 2009, Trierveiler-Pereira \& Baseia 2009), Rio Grande do Sul (Rick 1961) and Paraná (De Meijer 2006). This represents the first record for Paraguay.

Material examined - Paraguay, Central Department, City of San Lorenzo, University Campus, Oct 2013, M. Campi 31 (HFACEN).

Pisolithus arhizus (Scop.) Rauschert, Zeitschrift für Pilzkunde 25(2): 50 (1959). $\quad$ Figs. 1, 2, 12,13 Mature basidiomata 5.2-6 cm diam., epigeous, variable shapes: globose to subglobose, claviform to pyriform, constrict in the basal part to form a short and irregular stipe 2-2.6 cm length. In the lower part of it an olive green to yellowish mycelial cord grows with incrustations of the substrate strongly adhered. Peridium thin $\pm 1 \mathrm{~mm}$ thick, smooth and hard, solid and heavy appearance, yellowish brown, it tears leaving localized olive to black spots. Peridium hyphae 5.3$5.6 \mu \mathrm{m}$ diam., hyaline, thin and smooth walls, with septa and clamps. Gleba tough, compact and multilocular, divided in strati or mosaics composed by irregular and angular pseudoperidioles 4 x 2 $\mathrm{mm}$. The color varies with the degree of maturation; in the basal part they are yellow of slimy texture, in the middle portion they are light brown with some yellow lines, and in the upper part they are dark brown of dusty texture; this delimitation of colors suggests that the maturation occurs from the apex to the base; at maturity it becomes a dry and dusty structure with hard consistency. Gleba hyphae septate with clamps pp $\mu$ m diam. Spores spherical with spines, 8-10 $\mu \mathrm{m}$ without including the spines, which are up to $2 \mu \mathrm{m}$ long. Septate hyphae, with clamps, 5.3-5.6 $\mu \mathrm{m}$ in both peridium and gleba, amyloid, hyaline in $\mathrm{KOH}$.

Habitat - Gregarious or solitary. Found on soil near Pinaceae plants.

Known distribution - In Brazil it is cited for the States of Espirito Santo (Vinha 1988), São Paulo (Bononi et al. 1981), and Rio Grande do Sul (Guerrero \& Homrich 1999). This represents the first record for Paraguay.

Material examined - Paraguay, Central Department, City of San Lorenzo, University Campus, Aug 2013, M. Campi 35 (HFACEN).

Notes - This species is considered edible when immature (García et al. 2006). It is used in reforestation to restore degraded systems forming mycorrhiza (Roldan et al. 1996).

Scleroderma bovista Fr., Syst. mycol. (Lundae) 3(1): 48 (1829).

Figs. 3, 4, 14-16

Basidiomata 1,5-4,5 $\mathrm{cm}$ diam., globose to subglobose, sessile or with a rudimentary pseudostipe, base with groups of compact mycelial threads strongly adhered to the substrate. Peridium 0,9-1,4 mm thick, beige or pale yellow to dark brown, smooth to verrucose with tiny brown scales, rubbery when fresh, coriaceuos when dry. The dehiscence occurs in the apical part where it breaks into vertical grooves. Gleba grayish at maturity, powdery, with yellowish to auburn veins. Exoperidium composed of cylindric hyphae, $5 \mu \mathrm{m}$ diam., thin-walled, hyaline to yellowish, congophilic. Chain of spheric hyphae, thin-walled, 10-12 $\times 5-8 \mu \mathrm{m}$ diam. encrusted with crystals, some with clamps; inner layer composed of thin-walled cylindrical hyphae, 5-6 $\mu \mathrm{m}$ diam. Spores 11-16 $\mu \mathrm{m}$ including spines, globose, reticulated, reticulum 1-3 $\mu \mathrm{m}$ in lenght, gold brown, dark in $\mathrm{KOH}$.

Habitat - gregarious, growing on soil.

Known distribution - From Brazil (Guzmán 1970), for the states of: Santa Catarina (Giachini et al. 2000 - as Scleroderma fuscum [Corda] E. Fisch.), Pernambuco (Gurgel et al. 2008), for Argentina: Buenos Aires (Spegazzini 1880, Guzmán 1970, Wright \& Albertó 2006), La Pampa (Domínguez De Toledo 1989) and Misiones (Guzmán 1970). This represents the first record for Paraguay.

Examined material - Paraguay, Central Department, City of San Lorenzo, University Campus, Aug 2013, M. Campi 44 (HFACEN). 


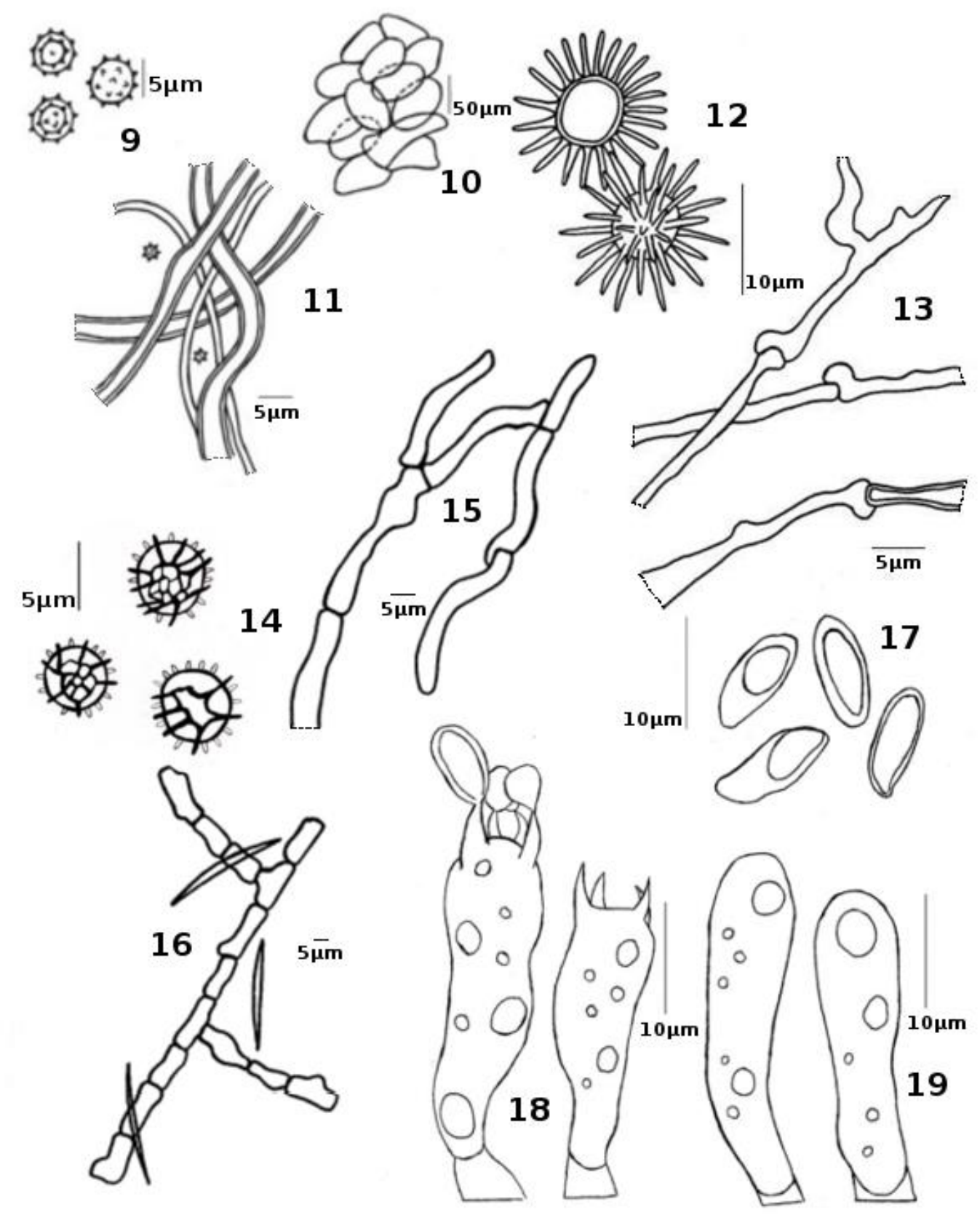

Figs 9-11 - Geastrum minimun: 9 Spores. 10 Pseudoparenchymatous layer. 11 Capillicium hyphae. Figs 12-13 - Pisolithus arhizus: 12 Spores. 13 Exoperidium hyphae. Figs 14-16 Scleroderma bovista: 14 Spores. 15 Hyphae from the outer layer of the exoperidium. 16. Inner layer of the exoperidium hyphae Figs 17-19 - Suillus granulatus: 17 Spores. 18. Basidia. 19 Cystidia.

Notes - Nouhra (2012) explains that this is a common species in plantacions, parks and forest of pines in Argentina. The combination of spines and reticulum in the wall of the spores and the color of the peridium separates S. bovista from the Scleroderma species of the region.

Suillus granulatus (L.) Roussel, Flore du Calvados et terrains adjacents, composée suivant la méthode de Jussieu: 34. (1806)

Figs. 5, 6, 17-19

Pileus 20-60 mm diam., convex to flat, moist surface, slimy, smooth, yellow-brown to reddish-brown, margin whole and curved. Cuticle smooth and slimy, separates easily from the cap. Hymenium poroid, adnate short tubes, 3-5 $\mathrm{mm}$ in length, whitish when young, yellowing with age; toward the hymenial surface the tubes end in angular pores, yellowish, 1-2 per mm. Context fleshy yellowish. Stipe 15-45 × 5-13 mm, central to slightly eccentric, whitish when immature, yellowish 
with age, solid, cylindrical, with apical characteristics granulations, reddish to chestnut, with white mycelium at the base. No ring. Spores $9-11 \times 2-4 \mu \mathrm{m}$, ellipsoidal, fusiform, with small apex and center gutule, smooth, yellowish-brown in mass, inamyloid. Basidia 18-30 × 5,5-7 $\mu \mathrm{m}$, clavate, 4 sporated, no clamps. Cystidia 16-30 $\times 5-6,5 \mu \mathrm{m}$, fusiform with brownish gutules. Pileipellis cutis type, formed by cylindrical entangled gelled hyphae.

Habitat - on soil. Winter to autumn season. Over three individuals.

Known distribution - In Brazil for the state of Santa Catarina (Giachini et al. 2000); in Argentina for the states of Entre Ríos, Tucumán, Corrientes, Misiones (Niveiro et al. 2009) and Buenos Aires (Niveiro et al. 2009, Deschamps 2002).

Material examined - PARAGUAY, CENTRAL DEPARTMENT, City of San Lorenzo, University Campus, May 2013, M. Campi 62 (HFACEN).

Notes - In young specimens is characteristic the exudation of whitish latex droplets on the hymenium, than later drop to the stipe and leave the granulations features. Blanco et al. (2012) explains that ecologically the Suillus species are ectomycorrhizal which establish symbiosis with conifers, especially pines (Pinus spp.), being typical of young pine forests and reforestation. Niveiro et. al (2009) mentions that are distributed almost worldwide, coinciding with the area of the host species which are spread across much of the world due to reforestation.

\section{Acknowledgements}

We thank Dr. Gabriel Moreno for his invaluable assistance in the identification of the samples, PhD. Larissa Trierveiler-Pereira for the help with the identifications of specimens, and MSc. Danilo Fernandez for the help in drafting.

\section{References}

Becerra A, Zak M. 2011 - The Ectomycorrhizal Symbiosis in South America: Morphology, Colonization, and Diversity. Soil Biology 25, 19-41.

Blanco D, Fajardo J, Verde A, Rodríguez C. 2012 - Etnomicología de los hongos del género Suillus, una visión global. Bol. Soc. Micol. Madrid 36.

Bononi V, Trufem S, Grandi R. 1981 - Fungos macrocópicos do Parque Estadual das Fontes do Ipiranga, Sâo Paulo, Brasil, depositados no Herbário do Instituto de Botânica. Rickia 9, 3753.

Calonge F, Mata M, Carraza J. 2005 - Contribución al catálogo de los Gasteromycetes (Basidiomycotina, Fungi) de Costa Rica. Anales del Jardín Botánico de Madrid 62(1), 23 45.

Deschamps JR. 2002 - Hongos silvestres comestibles del Mercosur con valor gastronómico. Documento de Trabajo $\mathrm{N}^{\circ} 86$, Universidad de Belgrano

De Meijer A. 2006 - Preliminary list of the macromycetes from the Brazilian State of Paraná. Bol. Mus. Bot. Munic. 68, 1-59.

Domínguez De Toledo L. 1989 - Contribución al conocimiento de los Gasteromycetes del centro de la Argentina. Tesis doctoral. Facultad de Ciencias Exactas, Físicas y Naturales. Universidad Nacional de Córdoba. Argentina.

Dustan W, Dell B, Malajczuk N. 1998 - The diversity of ectomycorrhizal fungi associated with introduced Pinus spp. in the Southern Hemisphere, with particular reference to Western Australia. Mycorrhiza 8, 71-79.

Enciso, V. 2002 - Estado actual de la información sobre árboles fuera de bosque. Estado de la información forestal en Paraguay 14, 9-20.

Figueroa, A. 2007 - Variación de densidad básica en la madera de Pinus taeda L. Tesis de grado. Universidad Austral de Chile. Valdivia.

Fazolino, E. 2009 - O gènero Geastrum Pers. (Phallomycetidae, Basidiomycota) em algumas áreas de Mata Atlantica e Caatinga no Rio Grande do Norte, Brasil. Tese M.S. Universidade Federal do Rio Grande do Norte, Rio Grande Do Norte. 
García J, Pérez-Moreno J, Aldrete A, Cetina-Alcalá V, Vaquera-Huerta H. 2006 - Caracterización del hongo silvestre ectomicorrízico Pisolithus tinctorius (Pers.) Coker et Couch en cultivo y en simbiosis con eucalipto y pino. Agrociencia 40, 665-676.

Giachini A, Oliveira L, Castellano M, Trappe J. 2000 - Ectomycorrhizal fungi in Eucalyptus and Pinus plantations in Southern Brazil. Mycologia 92, 1166-1177.

Guerrero RT, Homrich MH. 1999 - Fungos Macroscópicos Comuns no Rio Grande do Sul - Guia para Identificação. 2a ed. Porto Alegre: Ed. UFRGS.

Gurgel F, Silva B, Baseia I. 2008 - New records of Scleroderma from Northeastern Brazil. Mycotaxon 105, 399-405.

Guzmán G. 1970 - Monografía del género Scleroderma. Darwiniana 16, 233-407.

Hibbett D. et. al. 2007 - A higher-level phylogenetic classification of the Fungi. Mycological research 111, 509-547.

Larrobla R, Berni C. 1982 - Información Preliminar sobre el comportamiento de procedencias de Pinus elliotti, Engelm. var. elliotti y Pinus taeda L. en San Lorenzo, Paraguay. Revista Forestal. Facultad de Ingeniería Agronómica-UNA 1(1), 1-6.

López J. 1974 - Temas Forestales del Paraguay. Editorial del Ministerio de Agricultura y Ganadería, Asunción-Paraguay. 39-45.

Morales J, Carneiro C, Serrano O. 2002 - Estado de la Información Forestal en Paraguay. Información y Análisis para el Manejo Forestal Sostenible: Integrando esfuerzos Nacionales e Internacionales en 13 países tropicales en América Latina. FAO. Santiago, Chile. ftp://ftp.fao.org/docrep/fao/006/ad390s/ad390s00.pdf (accessed 12 Nov 2014)

Niveiro N, Popoff O, Albertó E. 2009 - Hongos Comestibles Silvestres: especies exóticas de Suillus (Boletales, Basidiomycota) y Lactarius (Russulales, Basidiomycota) asociadas a cultivos de Pinus elliottii del nordeste argentino. Bonplandia 18, 65-71.

Noguera M. 2003 - Estudio del crecimiento de Pinus taeda L. y Pinus elliottii Engelm, en la localidad de Pirapó, Departamento de Itapua. Tesis para grado de Ingeniero Forestal. Universidad Nacional de Asunción, San Lorenzo.

Nouhra E, Hernandez M, Pastor N. 2012 - The species of Scleroderma from Argentina, including a new species from the Nothofagus forest. Mycologia 104(2), 488-495.

Read DJ, Perez Moreno J. 2003 - Mycorrhizas and nutrient cycling in ecosystems -a journey towards relevance? New Phytol. 157, 475-492.

Rick J. 1961 - Basidiomycetes Eubasidii no Rio Grande do Sul - Brasília 6. Iheringia, Série Botânica 9, 451-480.

Roldan A, Querejeta I, Albaladejo J, Castillo V. 1996 - Growth response of Pinus halepensis to inoculation with Pisolithus arhizus in a terraced rangeland amended with urban refuse. Plant and Soil 179, 35-43.

Spegazzini C. 1880 - Fungi Argentini. Pugillus 3. Anales de la Sociedad Científica Argentina 10 (5-6), 145-168

Sunhede S. 1989 - Geastraceae (Basidiomycotina) morphology, ecology and systematics with emphasis on the north Europearn species. Synopsis Fungorum 1. Oslo: Fungiflora. 535 pp.

Trierveiler-Pereira L, Baseia IG. 2009 - A checklist of the Brazilian gasteroid fungi (Basidiomycota). Mycotaxon 108, 441-444.

Trierveiler-Pereira L, Da Silveira RMB. 2012 - On the Geastrum species (Geastraceae, Basidiomycota) described by Rick. Phytotaxa 61, 37-46.

Vinha PC. 1988 - Fungos macroscópicos do estado do Espírito Santo depositados no herbário central da Universidade Federal do Espírito Santo, Brasil. Hoehnea 15, 57-64.

Wright J, Albertó E. 2006 - Hongos de la Región Pampeana. II. Hongos sin laminillas. Buenos Aires: L.O.L.A. 412 p. 